\title{
アルミニウム合金の冷間圧延における潤滑に及ぼす バックアップロールの影響
}

\author{
杉井 秀夫 ${ }^{1 *}$. 宇都宮 裕 $^{2}$
}

Journal of The Japan Institute of Light Metals, Vol. 69, No. 2 (2019), 120-124

(C) 2019 The Japan Institute of Light Metals

\section{Effects of back-up rolls on lubrication in cold rolling of aluminum alloy}

\author{
Hideo SUGII ${ }^{*}$ and Hiroshi UTSUNOMIYA ${ }^{2}$
}

It is known that roll coating is formed on work rolls in cold rolling of stainless steel, copper alloys or aluminum alloys. It affects surface properties of rolled strip, rolling characteristics and amount of wear debris formed. By the way, actual rolling mills have back-up rolls, which are equipped in order to reduce the deflection of the work rolls. In this study, cold rolling of A1-Mg alloy A5182 is conducted in laboratory to investigate the effects of backup rolls, on the rolling lubrication with a pair of back-up rolls which have groove at the center of the barrel. The backup roll does not contact with the roll coating on work roll when using the grooved backup-roll. As a result, it is found that the attainable maximum reduction in thickness is reduced by approximately 10 point compared with the case using normal flat back-up rolls. In addition, cold rolling of aluminum A1050 is conducted to investigate the effects of back-up rolls, on amount of wear debris formed in rolling lubricant. As a result, it is found that in the case of normal flat back-up rolls, the amount of wear debris is pronounced than the case of grooved back-up rolls.

(Received September 25, 2018 Accepted December 3, 2018)

Keywords: lubricant; rolling oil; roll coating; cold rolling; back-up roll

\section{1. 緒言}

ステンレス鋼および銅やチタンとその合金の冷間圧延で は，ワークロールに「ロールコーティング」と呼ばれる薄い コーティングが被加工材からの移着物によって生成し, 圧延 板の表面性状や圧延性, 圧延摩耗粉の発生量等に影響を及ぼ すことが知られている ${ }^{1) \sim 8)}$ 。

アルミニウムおよびその合金の冷間圧延においても， ワー クロールにロールコーティングが顕著に生成し, 加工時に圧 延摩耗粉が発生しやすい 9 , 10)。特に工業用純アルミニウム や電解コンデンサーなどに使用される高純度アルミニウムの 冷間圧延においては, 圧延摩耗粉の発生量が多く製品表面に 付着する圧延摩耗粉の低減が課題となっている ${ }^{11)}$ 。

ところで実生産の圧延機は，ワークロールの板幅方向のた わみを抑制し，板形状を改善する目的で，中間ロールやバッ クアップロールが用いられる。ワークロールの機械的な補強 以外の圧延に及ぼす影響はほとんど報告されていない。しか しこれらロールはワークロールのロールコーティングと常に 直接接触しているため，ロールコーティングの生成や圧延 潤滑性に影響を与えると考えられる ${ }^{12)}$ (15)。特にロールコー ティングが生成しやすい金属であるアルミニウム，ステンレ
ス鋼，黄銅，チタン等の圧延潤滑シミュレーションにはバッ クアップロールの影響も考慮する必要がある。

本研究では，4Hiの小型圧延機を用いてアルミニウム材の 冷間圧延実験を行い, 圧延潤滑と圧延摩耗粉発生量に及ぼす バックアップロールの影響を実験室的に調査した。実験 1 で はアルミニウム合金A5182材を用いて, バックアップロール が圧延潤滑性（耐焼付き性）に与える影響について調査した。

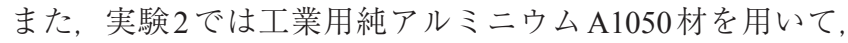
圧延摩耗粉の発生量に対するバックアップロールの影響を調 査した。

\section{A5182材の実験（実験 1）}

\section{1 実験方法}

用いた小型圧延機の主な仕様を Table 1 に示す。ワーク ロールとバックアップロールの胴長はいずれも $200 \mathrm{~mm}$ であ る。実験 1 はフラットなバックアップロールを用いた条件 1 と, 上側バックアップロールの中央に幅 $50 \mathrm{~mm}$, 深さ $0.2 \mathrm{~mm}$ の浅い切り欠きをつけた条件 2 の 2 条件で実施した。条件 1 と条件2のロール構成を Fig. 1 に，条件2で用いた上側バッ クアップロールの実験前の外観写真を Fig. 2 に示す。

条件2のバックアップロールの切り欠き部では，バック

${ }^{1}$ 出光興産株式会社 潤滑油二部 潤滑技術二課（†100-8321＼cjkstart東京都千代田区丸の内 3-1-1） Idemitsu Kosan Co., Ltd. (3-1-1, Marunouchi, Chiyoda-ku, Tokyo 100-8321)

2 大阪大学大学院工学研究科マテリアル生産科学専攻（吹田市） Division of Materials and Manufacturing Science, Graduate School of Engineering, Osaka University (Suita-shi, Osaka)

*責任著者E-mail: hideo.sugii@idemitsu.com 
Table 1 Specifications of the laboratory mill.

\begin{tabular}{l|l|c}
\hline \hline \multicolumn{2}{c|}{ Mill type } & $\begin{array}{c}\text { Reversing 4Hi } \\
\text { (Back-up roll drive) }\end{array}$ \\
\hline \multirow{5}{*}{ Work Roll } & Diameter, mm & 135 \\
& Roughness Ra, $\mu \mathrm{m}$ & 0.25 \\
& Material & SUJ-2 \\
& Hardness & Hs90 \\
\hline \multirow{5}{*}{ Back-up Roll } & Diameter, mm & 200 \\
& Roughness Ra, $\mu \mathrm{m}$ & 0.40 \\
& Material & $\mathrm{SUJ}-2$ \\
& Hardness & Hs80 \\
\hline
\end{tabular}

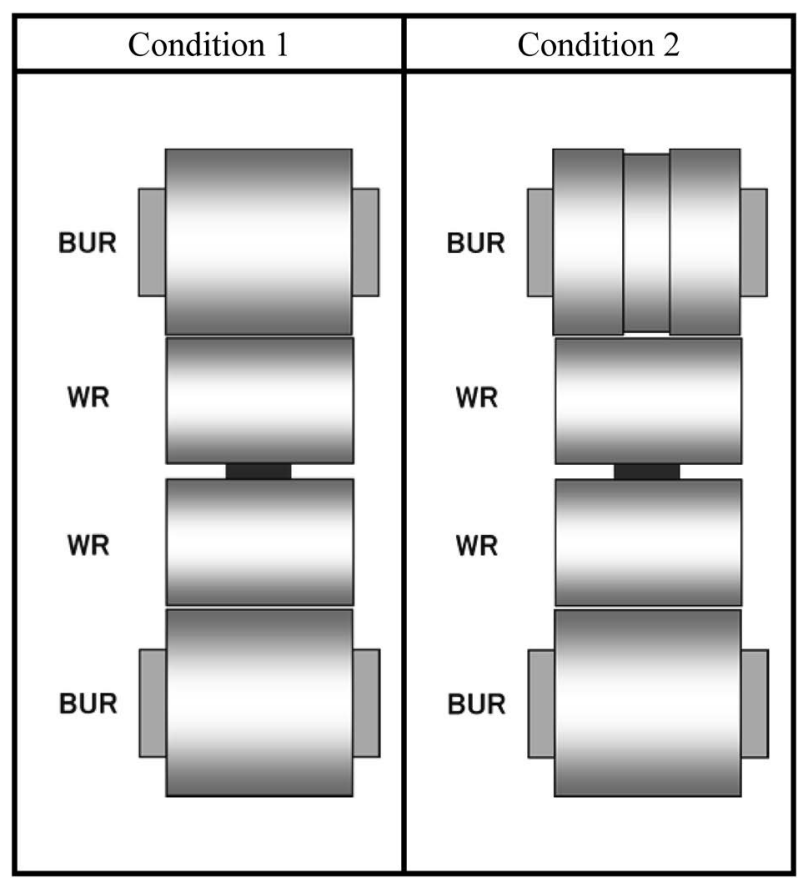

Fig. 1 Schematic of roll arrangements.

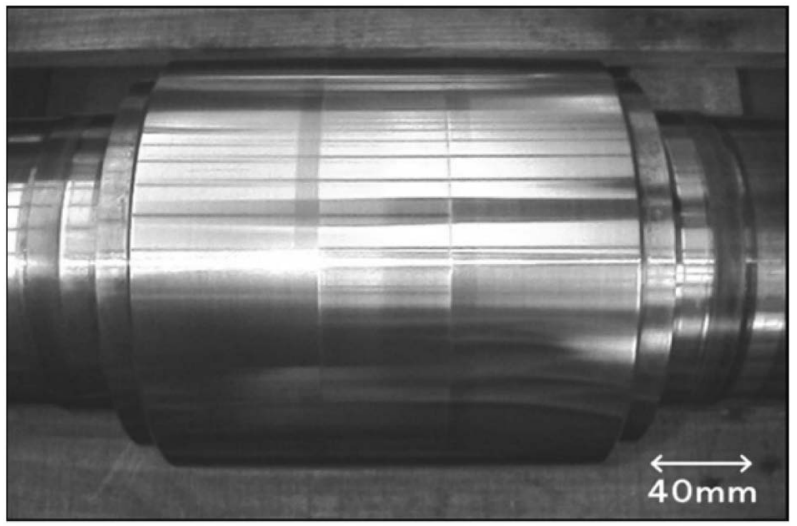

Fig. 2 Photograph of grooved back-up roll.

アップロールとワークロールが接触しないため, ワークロー ルの通板部はバックアップロールを持たない $2 \mathrm{Hi}$ 圧延相当と みなすことができる。条件 1 と条件 2 の実験結果を比較する ことにより，バックアップロールが圧延潤滑性に与える影響 を調査した。
Table 2 Properties of test lubricants.

\begin{tabular}{l|c|c|c}
\hline \hline \multicolumn{1}{c|}{ Item } & Unit & Experiment 1 & Experiment 2 \\
\hline $\begin{array}{l}\text { Kinematic Viscosity } \\
\left(40^{\circ} \mathrm{C}\right)\end{array}$ & $\mathrm{mm}^{2} / \mathrm{s}$ & 3.882 & 4.450 \\
Acid Value & $\mathrm{mgKOH} / \mathrm{g}$ & 0.00 & 0.00 \\
Hydroxyl Value & $\mathrm{mgKOH} / \mathrm{g}$ & 15.0 & 14.0 \\
Saponification Value & $\mathrm{mgKOH} / \mathrm{g}$ & 2.0 & - \\
\hline
\end{tabular}

Table 3 Rolling conditions of Experiment 1.

\begin{tabular}{c|c|c|c|c|c}
\hline \hline Pass & Thickness, \\
No. & $\mathrm{mm}$ & $\begin{array}{c}\text { Reduction, } \\
\%\end{array}$ & $\begin{array}{c}\text { Rolling speed, } \\
\mathrm{m} / \mathrm{min}\end{array}$ & \multicolumn{2}{|c}{ Tension, $\mathrm{kN}$} \\
\cline { 5 - 6 } & & - & - & - & - \\
\hline- & 1.000 & - & 100 & 0.78 & 0.49 \\
\hline $1-1$ & 0.530 & 47.0 & 100 & 0.78 & 0.49 \\
$1-2$ & 0.510 & 49.0 & 100 & 0.78 & 0.49 \\
$1-3$ & 0.490 & 51.0 & 100 & 0.78 & 0.49 \\
$1-4$ & 0.470 & 53.0 & 100 & 0.78 & 0.49 \\
$1-5$ & 0.450 & 55.0 & 100 & 0.78 & 0.49 \\
$1-6$ & 0.430 & 57.0 & 100 & 0.78 & 0.49 \\
$1-7$ & 0.410 & 59.0 & 100 & 0.78 & 0.49 \\
$1-8$ & 0.390 & 61.0 & 100 & 0.78 & 0.49 \\
$1-9$ & 0.370 & 63.0 & 100 & 0.78 & 0.49 \\
$1-10$ & 0.350 & 65.0 & 100
\end{tabular}

\section{1.1 供試材}

実生産の圧延工程において，焼付きの発生が課題となって いるアルミニウム合金を供試材に選定した。圧延材は板厚 $1.0 \mathrm{~mm}$, 板幅 $70 \mathrm{~mm}$ の JIS H4000に規定されている $\mathrm{A} 5182 \mathrm{H}$ （Al-Mg-Mn合金）コイルを用いた。

\section{1 .2 供試油}

$40^{\circ} \mathrm{C}$ における動粘度が $3.8 \mathrm{~mm}^{2} / \mathrm{s}$ の含芳香族系鉱物油に, アルミニウムおよびその合金用冷間圧延油の油性剤として一 般的に使用される工業用ラウリルアルコール $5 \mathrm{mass} \%$ と工業 用ブチルステアレート $1 \mathrm{mass} \%$ を配合したものを供試油とし た。供試油の性状を Table 2 に示す。

供試油は $40^{\circ} \mathrm{C}$ に調整してポンプで循環させ，ノズルから ワークロールおよび圧延材にスプレー給油した。

\section{1 .3 実験条件}

圧延実験条件を Table 3 に示す。圧延は 1 パスで実施し, 所定の速度で圧延しながら，20m長の圧延ごとに圧下率を 1-1，1-2，，と段階的に上げる方法で段階圧延して，条件 1 と条件 2 の圧延潤滑性を評価した。なお，圧延実験に用い るワークロールとバックアップロールは, 圧延実験ごとに所 定の表面粗さに再研磨したものを用いた。

\section{2 実験結果}

条件 1 では Table 3 中の 1-10パスまで圧延でき, 実測の板厚 から求めた最大圧下率は $65.1 \%$ であった。条件 2 では Table 3 中の1-8パスで圧延荷重が急に増大し, 圧延荷重をさらに大 きくしてもそれ以上は圧下できなかったため 1-8パスを圧延 限界と判断して，パススケジュールの途中であったが圧延を 


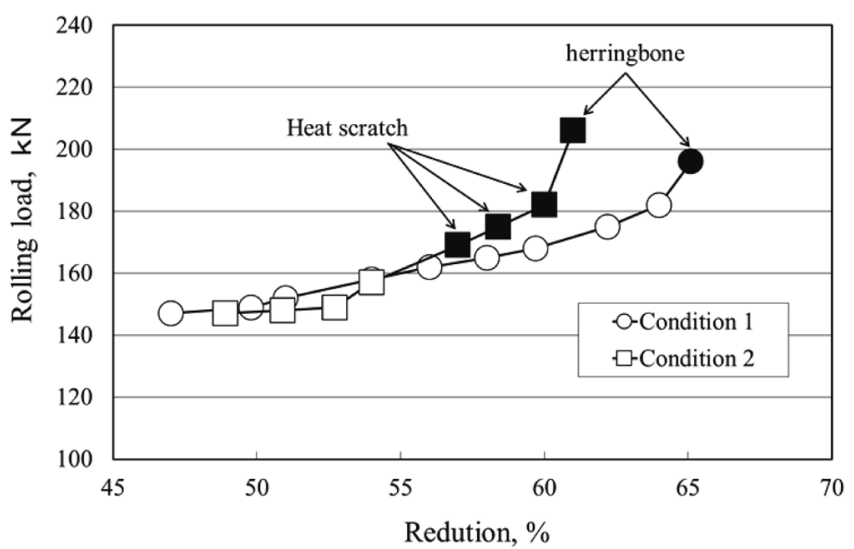

Fig. 3 Relationship between rolling load and reduction.

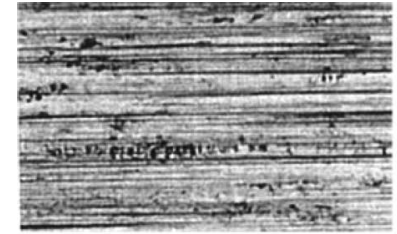

1-9Pass (Reduction 64.0\%)

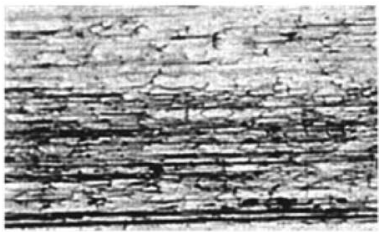

1-10Pass (Reduction 65.1\%) (a) Condition 1

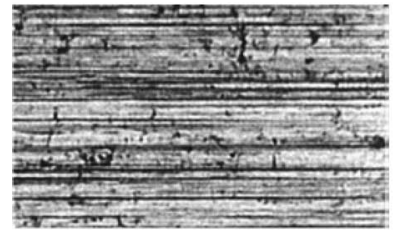

1-4Pass (Reduction 54.0\%)

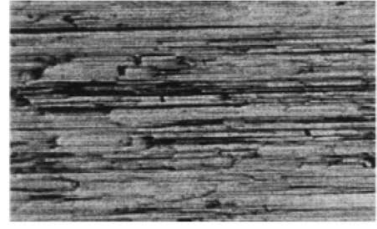

1-5Pass (Reduction 57.0\%) (b) Condition 2

\section{$50 \mu \mathrm{m}$}

Fig. 4 Optical micrographs of strip surface. Rolling direction is from left to right.

中止した。

圧延荷重と実測圧下率の関係を Fig. 3 に，圧延板の光学顕 微鏡写真を Fig. 4 に示す。条件 1 では圧下率 64.0\%（1-9パス） まで正常に圧延することができ，その圧延板表面にはロール の研磨目の転写が認められるのみでヒートスクラッチ（焼 付き疵）は認められなかった。圧下率65.1\%（1-10パス）で 圧延板表面に表面損傷形態の一つであるへリングボーンの発 生 ${ }^{16)}$ が認められた。一方で上側バックアップロールの中央 に切り欠きがある条件2では，圧下率54.0\%（1-4 パス）まで 正常に圧延することができ，圧下率 $57.0 \%$ （1-5 パス）で圧 延板表面に軽度のヒートスクラッチが，圧下率61.0\%（1-8 パス）ではヘリングボーンの発生が認められた。

すなわち条件 1 と条件 2 の圧延潤滑性を比較した結果，条 件1の方が正常な圧延が可能な圧下率がおよそ10ポイントも 高く，圧延潤滑性が良好であった。

圧延実験後の上側ワークロールの写真をFig. 5 に示す。条 件1（1-10パス後），条件2（1-8パス後）ともに圧延板表面 に発生したへリングボーンの模様の転写が観察される。

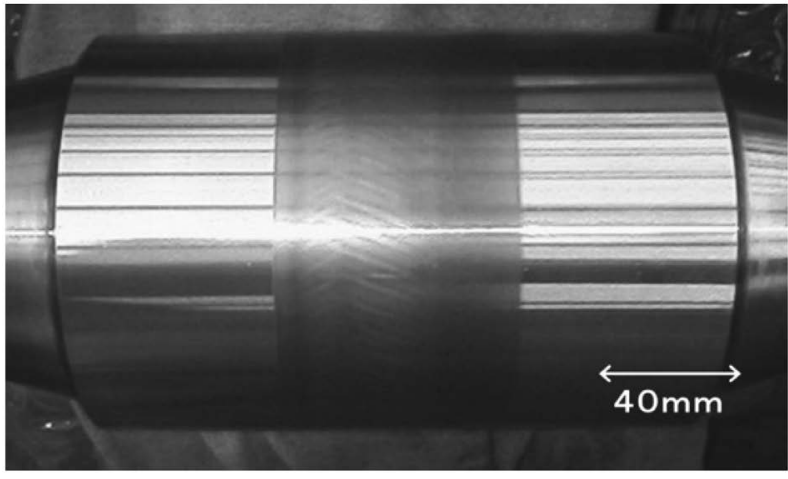

(a) Condition 1

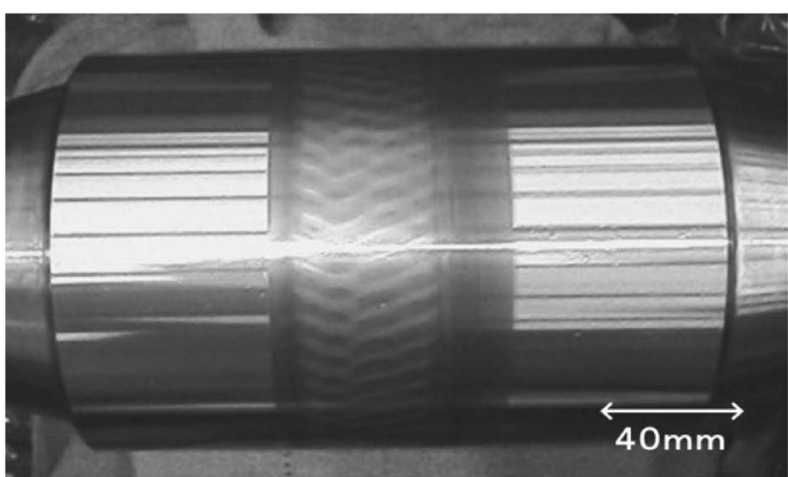

(b) Condition 2

Fig. 5 Photographs of upper work roll after rolling test.

\section{A1050材の実験（実験 2）}

\section{1 実験方法}

実験 1 と同様に，通常のバックアップロールを用いた条件 1 と，バックアップロールの中央に切り欠きをつけた条件 2 の 2 条件で実施し, バックアップロールが圧延摩耗粉の発生 量に与える影響を調査した。

小型圧延機の仕様は Table 1 と同じだが, ワークロールの 表面粗さは $\mathrm{Ra}=0.20 \mu \mathrm{m}$ で, 条件 2 のバックアップロールは上 側と下側のいずれにも切り欠きを付与し, その切り欠きの幅 は $70 \mathrm{~mm}$ とした。

3.1 .1 供試材

実生産の圧延工程において圧延摩耗粉の発生量が多く，低 減が目的とされている工業用純アルミニウム材を供試材とし て選定した。圧延材は板厚 $1.0 \mathrm{~mm}$, 板幅 $60 \mathrm{~mm}$ の JIS H4000 に規定されているA1050P（H24）（純度 99.50\% 以上のアルミ ニウム）コイルを用いた。

\section{1 .2 供試油}

$40^{\circ} \mathrm{C}$ における動粘度が $4.3 \mathrm{~mm}^{2} / \mathrm{s}$ の低芳香族ナフテン系 鉱物油に, アルミニウムおよびその合金用冷間圧延油の油 性剤として一般的に使用される工業用ラウリルアルコール 5 mass\%を配合したものを供試油とした。供試油の仕様を Table 2 に示した。

供試油は $40^{\circ} \mathrm{C}$ に調整したものをノズルからワークロール および圧延材にスプレー給油し，循環せずにかけ流しで使用 した。 


\section{1 .3 実験条件}

圧延実験条件を Table 4 に示す。圧延は1パスで実施し, 一定の速度と圧下率で圧延しながら，圧延中に圧延油を下側 バックアップロールの直下で採取した。

3.1.4 圧延摩耗粉量とロールコーティング量の測定方法 圧延摩耗粉は，圧延時に圧延油に混入する油中摩耗粉と圧 延板表面に付着する板上摩耗粉，ワークロール表面に付着す る摩耗粉の3つに大別することができる。油中摩耗粉の発生 量が最も多く，アルミニウムの圧延工場の重要な管理項目の 1つであることから，本研究では油中摩耗粉量について調査 した。油中摩耗粉量は, 圧延中に下側バックアップロールの 直下でおよそ $20 \mathrm{~m}$ 圧延するごとに供試油を採取し，採取し た供試油に $6 \mathrm{~N}$ の塩酸を加えて $40^{\circ} \mathrm{C} て ゙ ~ 15$ 分間攪拌して塩酸 層に溶解したアルミニウム濃度を ICPで測定して油中摩耗粉 量 $(\mathrm{mg} / 100 \mathrm{~g})$ を求めた。

ロールコーティング量は, 圧延実験後の上下のワークロー ルに生成したロールコーティングを $6 \mathrm{~N}$ の $\mathrm{KOH}$ 水溶液で溶 解し, 溶解液中のアルミニウム濃度を ICPで測定してロール コーティング量 $\left(\mathrm{mg} / \mathrm{m}^{2}\right)$ を求めた。

Table 4 Rolling conditions of Experiment 2

\begin{tabular}{c|c|c|c|c|c}
\hline \hline \multirow{2}{*}{$\begin{array}{c}\text { Pass } \\
\text { No. }\end{array}$} & $\begin{array}{c}\text { Thickness, } \\
\mathrm{mm}\end{array}$ & $\begin{array}{c}\text { Reduction, } \\
\%\end{array}$ & $\begin{array}{c}\text { Rolling speed, } \\
\mathrm{m} / \mathrm{min}\end{array}$ & \multicolumn{2}{|c}{ Tension, $\mathrm{kN}$} \\
\cline { 5 - 6 } & & & Entry & Exit \\
\hline- & 1.000 & - & - & - & - \\
1 & 0.600 & 40.0 & 100 & 1.18 & 0.59 \\
\hline
\end{tabular}

\section{2 実験結果}

\subsection{1 圧延荷重}

圧延距離 $150 \mathrm{~m}$ から $200 \mathrm{~m}$ の圧延荷重の平均は，条件2（切 り欠きつきバックアップロール）よりも条件1（通常バック アップロール）の方が約 $2 \%$ 大きく，表面損傷が発生してい ない圧下率条件での実験 1 と同じ傾向であった。

\section{2 .2 油中摩耗粉量}

圧延距離に対する油中摩耗粉量の推移を Fig. 6 に示す。条 件 2 よりも条件 1 の方が油中摩耗粉量は多く推移しており, バックアップロールとワークロールが直接接触することが油 中摩耗粉の発生量を増加させていることが示唆される。

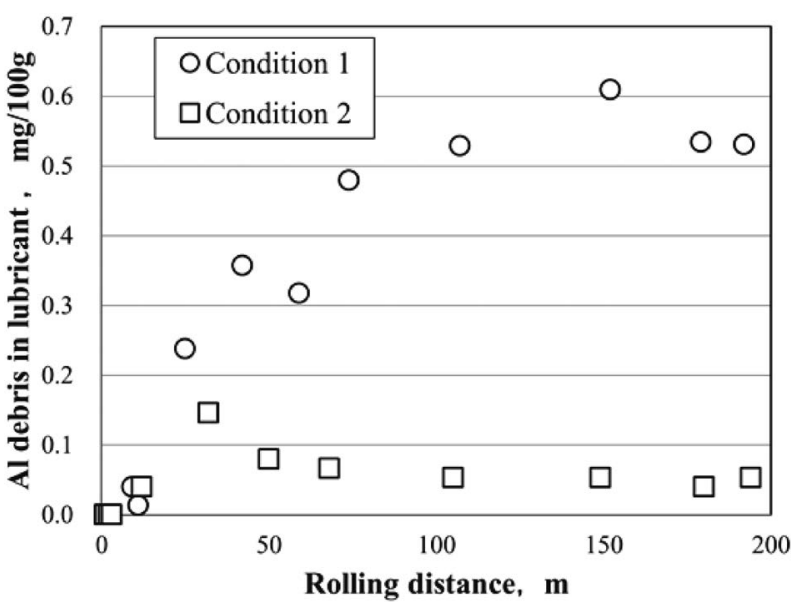

Fig. 6 Relationship between rolling distance and amount of $\mathrm{Al}$ debris in sampled lubricants.

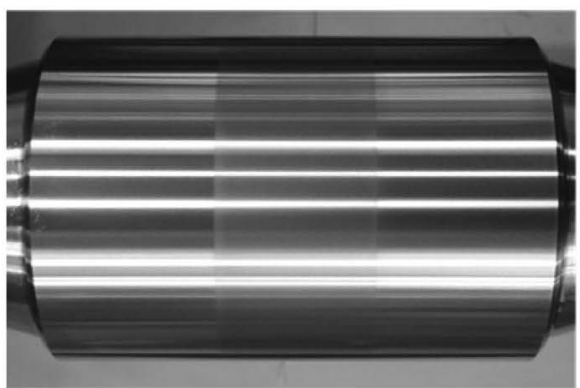

Upper roll

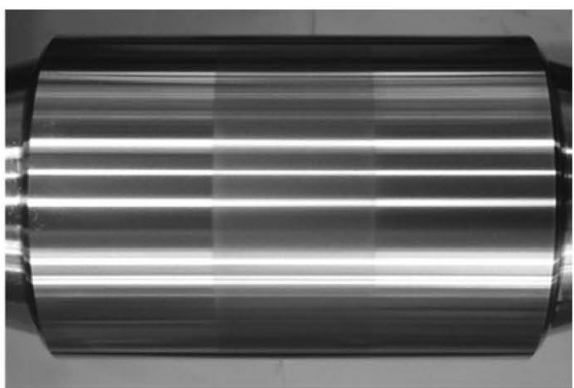

Lower roll

(a) Condition 1

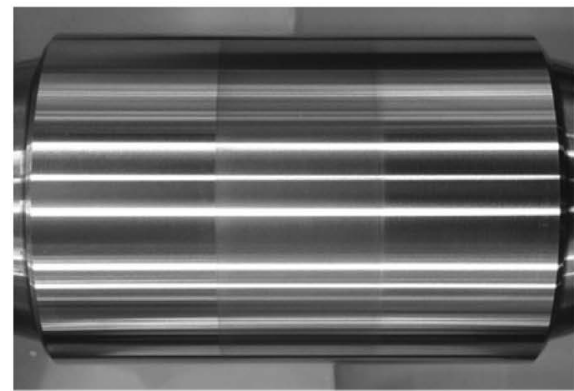

Upper roll

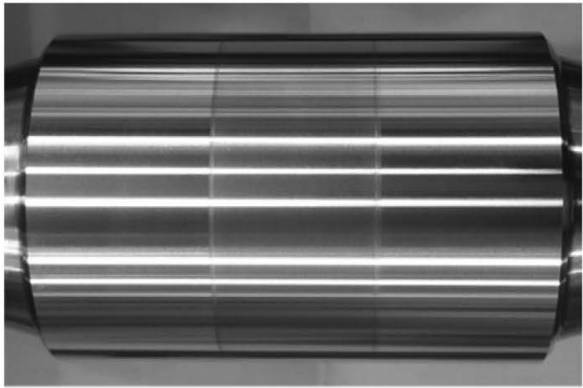

Lower roll

(b) Condition 2

Fig. 7 Photographs of work roll after rolling test. 


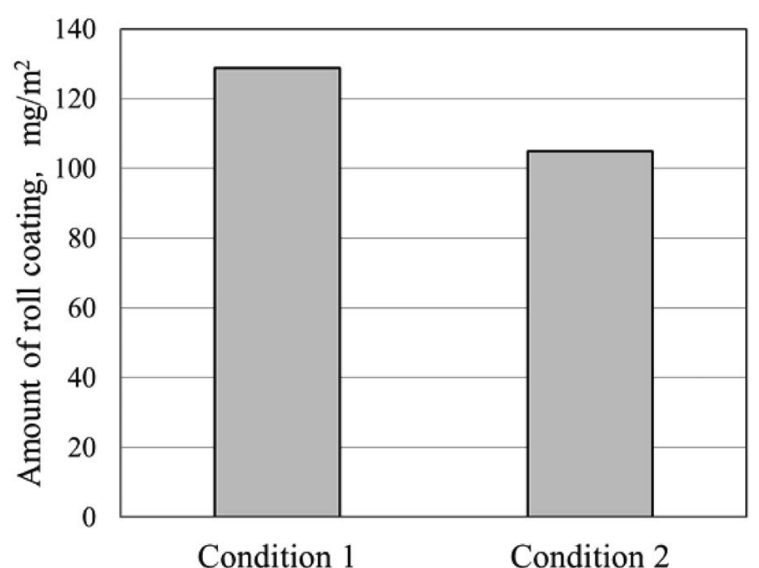

Fig. 8 Amount of roll coating on work rolls after rolling test.

\subsection{3 ロールコーティング量}

圧延実験後のワークロールの外観写真を Fig. 7 に，ロール コーティング量の測定結果を Fig. 8 に示す。ワークロールの 外観写真の比較から, 条件1（通常バックアップロール）の 方が条件2（切り欠きつきバックアップロール）よりもロー ルコーティングがやや濃く生成している。またロールコー ティング量の測定值も条件 1 の方が約 $23 \%$ 多い結果であり, このことを㙜付けている。

\section{4. 考察}

実験 1 の条件 2 で圧延板にヒートスクラッチが発生した 圧下率 $57.0 \%$ に打ける平均圧延圧力を計算により求めると $358 \mathrm{MPa}$ であり，この時の下側ワークロールと下側バック アップロールの接触圧力は, 最大ヘルッ圧力 $852 \mathrm{MPa}$, 平均 ヘルッ圧力 $568 \mathrm{MPa}$ と計算される。ワークロールとバック アップロールは圧延材との接触圧力に比較して 2 倍近い圧力 で接触している。このような接触圧力は, 圧延時に圧延材か らワークロールに移着したロールコーティングの一部をバッ クアップロールがこすり落とし, 残ったロールコーティング を押し固める働きをしていると考えられる。すなわち，バッ クアップロールがワークロールと接触しない条件 2 の場合に は，圧延材からワークロールに移着した金属が，バックアッ プロールと接触することなく，そのまま再度圧延材に接触す ることを繰り返すため共金摩擦を発生しやすく，凝着損傷を 発生しやすくするものと考えられる。

一方で，条件1のようにバックアップロールがワークロー ルと接触する場合には，ロールコーティングの軟らかい部分 はこすりとられ，さらには圧延圧力の 2 倍の圧力で固められ たコーティング表面が圧延材に接触していくため，共金摩擦 が発生しにくくなると考えられる。

実験 1 の結果より，ロールコーティングの発生しやすい金 属の圧延潤滑をシミュレーションする場合には, バックアッ プロールの潤滑効果を十分考慮する必要があることが明らか となった。

次に, 実験 2 は実験 1 と同様に, ワークロールとバックアッ プロールが接触しない条件 2 においては，バックアップロー
ルがロールコーティングの一部をこすり落とし，押し固める 効果がないため, 油中摩耗粉の生成量が条件 1 と比較して非 常に少なかったと考えられる。ロールコーティング量につい ても条件 2 はバックアップロールがロールコーティングを押 し固めることがなかったため少なかったと考えられる。

実験 1 および実験 2 の結果より，バックアップロールは ワークロールのたわみを抑えて圧延品の形状の精度向上に寄 与するだけでなく，ロールコーティングの生成を介して圧延 潤滑性に影響を与えていることが本論文で明らかとなった。

\section{5. 結言}

小型圧延機を用いてアルミニウム材の冷間圧延実験を行 い, 次の結果を得た。

(1）A5182材の圧延実験では，バックアップロールが圧 延潤滑性に与える影響について調査を行い, バックアップ ロールはワークロールのたわみを抑えて圧延品の形状制御に 寄与するだけでなく，ロールコーティングの生成を抑制して 共金摩擦による圧延潤滑性の低下を抑制し，耐焼付き性を向 上させる働きも有していることが確認された。

(2) A1050材の圧延実験では, バックアップロールの存 在が油中および板上摩耗粉の発生量を増加させていることが 確認された。

\section{謝 辞}

本研究の実験にあたり, 出光興産株式会社営業研究所加工 油グループ 志渡誠一氏, 長瀬直樹氏, 谷野順英氏にご協力 をいただきましたことを付記し謹んでお礼申し上げます。

\section{参 考 文 献}

1) P. Montmitonnet and E. Felder: 7th International Conference on Tribology in Manufacturing Processes, (2015), 62-73.

2) P. Montmitonnet, F. Delamare and B. Rizoulieres: Wear, 245 (2000), $125-135$.

3）志渡誠一, 今住則之, 菅野法仁, 田崎稔典, 澤 浩一, 川並高 雄：第47回塑性加工連合講演会講演論文集，（1996），281-282.

4) 小倉茂稔, 沢部寿宏, 関 克己, 遠藤和彦: 塑性と加工, 29 (1988), 498-503.

5) H. Sugii, N. Tanino and H. Utsunomiya: Proceedings. Asia Steel International Conference, 2015, (2015), 260-261.

6) 剣持一仁, 磯辺邦夫, 鑓田征雄, 福原明彦, 清野芳一, 赤沢 高：第46回塑性加工連合講演会講演論文集，(1995)，139-140。

7) 杉井秀夫：トライボロジスト, 55 (2010), 860-866.

8) 阿部賢太，松本 良，宇都宮裕：材料とプロセス, 28 (2014), No.167.

9) 小豆島明, 本山康貴, 石川道朗：第46回塑性加工連合講演会 講演論文集，(1995)，137-138.

10) 杉井秀夫, 松本貢一, 津田康宏 : 軽金属学会第 119 回秋期大会 講演概要，(2010)，143-144.

11）渡邊貴道：トライボロジスト， 55 (2010)，847-853.

12）志渡誠一, 杉井秀夫, 澤 浩一: 塑性加工春季講演会講演論文 集, (2001), 199-200.

13）谷野順英, 杉井秀夫, 宇都宮裕 : 日本鉄鋼協会第 170 回秋季講 演大会, 28 (2015), No.166.

14）谷野順英, 杉井秀夫, 松本貢一, 津田康宏, 宇都宮裕：材料と プロセス，29（2016），No.169.

15）杉井秀夫，谷野順英，宇都宮裕：銅と銅合金，52（2013）。 $81-86$.

16）志渡誠一：トライボロジスト，41（1996），363-368. 